\title{
PENGARUH MODEL GENERATIVE LEARNING TERHADAP KEMAMPUAN ANALISIS SISWA PADA MATERI SISTEM SARAF MANUSIA
}

\author{
Sulton Nawawi ${ }^{1}$, Fitri Oviyanti ${ }^{2}$, Ulul Faizah ${ }^{3}$ \\ ${ }^{1}$ Universitas Muhammadiyah, Jl. Jend. Ahmad Yani, 13 Ulu, SeberangUlu II, Palembang \\ ${ }^{2,3}$ Universitas Islam Negeri Raden Fatah, Jl. Prof. K.H. Z. A. Fikri, 1-A KM 3,5, Palembang \\ e-mail: sulton_nawawi@um-palembang.ac.id
}

\begin{abstract}
Analysis is a basic ability for students to think critically and include one of the high cognitive that were important to mastered students. Where the ability of high-level thinking was one of the goals of education in the 21st century. The purpose of this study was to determine the effect of Generative Learning model on the Ability of Student Analysis on Matter of Human Nervous System in Class XI IPA SMA Muara Lakitan Musi Rawas Regency. This research used Quasi Experiment method of Nonequivalent Control Group Design. The population of this research was the students of class XI IPA with sampling technique used nonprobability of purposive sampling. With the sample of research class XI IPA 1 and XI IPA 2 which amounted to 69 students. Technique of data collection used multiple choice test amounting to 15 question, observation of model execution, field notes and documentation. Based on analysis result of student's analysis ability showed that mastery of analysis ability indicator in experiment class $67,7 \%$ higher than control class that was 55,3\%. The improvement of analytical ability can be seen from the $N$-gain value where the experimental class has a gain value of 0,53 with medium category higher than control class that is 0.19 with low category. The results of hypothesis testing using $t$ test obtained tcount $=$ 3.969 and $t_{\text {table }}=1.670$ with $95 \%$ confidence level $(\alpha=0.05)$. The data shows that $t_{\text {count }}>t_{\text {table }}$, then $H_{0}$ is rejected and $H_{a}$ accepted. Thus, it can be concluded that the Generative Learning model has an effect on the students' analysis ability in the XI grade of SMA Negeri Muara Lakitan of Musi Rawas Regency.
\end{abstract}

Keywords: Analysis Ability, Generative Learning Model

\section{PENDAHULUAN}

Pendidikan merupakan suatu proses yang dilakukan dengan metode tertentu sehingga seseorang memperoleh pengetahuan, pemahaman, dan cara bertingkah laku yang sesuai dengan keperluan (Syah, 2010). Pendidikan harus dimiliki oleh semua peserta didik agar dapat mencapai kebahagiaan yang setinggi-tingginya dan dapat menghadapi tantangan pendidikan yang akan muncul.

Hasbullah (2013) juga telah mengatakan bahwa pendidikan sebagai tuntunan hidup anak-anak, agar mereka mencapai keselamatan dan kebahagiaan yang setinggi- tingginya. Untuk itu, peserta didik terlebih dahulu untuk mengetahui tujuan dari pendidikan sehingga, dapat mengetahui betapa pentingnya suatu pendidikan itu sendiri. Tanpa tujuan pendidikan yang jelas, kehidupan masyarakat, bangsa dan Negara akan tidak terpenuhi sepenuhnya maka dari itu, untuk menwujudkan tujuan tersebut ialah dengan belajar.

Dalam menghadapi tantangan abad 21, sumber daya manusia harus memiliki kemampuan berpikir tingkat tinggi. Kemampuan berpikir tingkat tinggi merupakan aspek penting dalam pengajaran dan pembelajaran. 
Kemampuan berpikir yang mendasar dalam proses pendidikan. Kemampuan berpikir sesorang dapat mempengaruhi kemampuan pembelajaran, kecepatan dan efektivitas pembelajaran. Oleh karena itu, keterampilan berpikir dikaitkan dengan proses belajar. Siswa yang dilatih untuk berpikir menunjukkan dampak positif pada pengembangan pendidikan mereka (Heongdkk., 2011).

Menurut Anderson \& David (2015), salah satu kemampuan berpikir tingkat tinggi adalah kemampuan menganalisis. Menganalisis merupakan proses yang melibatkan proses memecah-mecah materi menjadi bagian-bagian kecil dan menentukan bagaimana hubungan antara bagian dan antara setiap bagian dan struktur keseluruhannya. Menurut Atika, Isnaini \& Prasetyo (2012), kemampuan analisis merupakan kemampuan awal yang harus dikembangkan untuk mencapai kemampuan berpikir kritis. Kemampuan analisis memiliki peranan untuk memecahkan berbagai masalah dalam kehidupan sehari-hari.

Namun tingkat kemampuan analisis di Indonesia masih rendah, seperti hasil studi yang dilakukan OECD melalui program PISA (Program for International Student Assesment) tahun 2006, diperoleh bahwa hasil kemampuan sains siswa Indonesia berada pada tingkat 50 dari 57 negara. Skor rata-rata sains yang diperoleh siswa Indonesia pada saat itu adalah 393. Pada tahun 2012, persentase kemampuan sains siswa Indonesia adalah $63,4 \%$ dan mengalami sedikit peningkatan dari tahun-tahun sebelumnya. Pada tahun 2015 Presentase kemampuan siswa sedikit mengalami peningkatan kembali menjadi 68,2 \% (Kemendikbud, 2015).

Hasil tes awal kemampuan analisis yang telah dilakukan di SMA Negeri Muara Lakitan kemampuan analisis siswa masih sangat rendah hal tersebut dapat dilihat dari hasil tes siswa secara keseluruhan menunjukan rata-rata skor 41,89 dari skor ideal 100 untuk kelas XI IPA 1, sedangkan hasil tes siswa kelas XI IPA 2 secara keseluruhan menunjukan rata-rata skor 30,37 dari skor ideal 100. Hal tersebut dapat disebabkan karena siswa belum terlatih untuk menganalisis suatu permasalahan dalam pembelajaran karena siswa jarang diberikan soalsoal evaluasi pada jenjang kognitif $\mathrm{C} 4$, sehingga kemampuan siswa dalam jenjang C4 kurang berkembang.

Salah satu upaya meningkatkan kemampuan analisis siswa yaitu dengan menggunakan model pembelajaran yang menarik, membantu siswa dalam memahami konsep materi dan menghubungkan konsep yang telah di miliki dengan dunia nyata (Nurmalasari, 2016). Salah satu model pembelajaran yang sesuai yaitu dengan model Generative Learning. Model pembelajaran ini merupakan model yang didesain menurut pandangan kontruktivisme. Teori Kontruktivisme memandang pengetahuan tidak dapat ditransfer begitu saja dari seseorang ke orang lain, tetapi harus diinterpretasikan sendiri oleh masing-masing orang dan setiap orang harus mengkontruksikan pengetahuan sendiri oleh masing-masing orang (Ratumanan, 2015).

Model Generative Learning adalah model pembelajaran dimana siswa harus dapat menjelaskan apa yang sedang dipelajari kemudian mengorganisasikan informasi yang sudah diseleksi berdasarkan pengalaman yang sesuai, dan logis. Menurut Wena (2014), Generative Learning terdiri dari empat tahapan, yaitu : Pendahuluan atau disebut tahapan Eksplorasi, Pemfokusan, Tantangan, dan Penerapan.

Menurut Osborne dan Wittrock dalam Sugilar (2013) bahwa, esensi Generative 
Learning adalah pikiran manusia bukanlah penerimaan informasi secara pasif, tetapi aktif mengkontruksi dan menafsirkan informasi untuk menarik kesimpulan berdasarkan informasi tersebut. Model Generative Learning berkaitan dengan kemampuan analisis, hal ini dapat dilihat pada fase pemfokusan, siswa dituntut untuk mengajukan hipotesis, kemudian pada fase tantangan, siswa dituntut untuk dapat mengeluarkan ide dan pada fase penerapan, siswa dituntut untuk dapat memecahkan masalah dengan konsep barunya.

Berdasarkan penelitian yang telah dilakukan oleh Ratri, Suciati \& Sugiyarto. (2016), model Generative Learning efektif untuk meningkatkan hasil belajar kognitif dan psikomotor siswa, tetapi tidak pada hasil belajar afektif siswa. Selain itu penelitian yang telah dilakukan Wijaya dkk (2014), model pembelajaran generatif dapat meningkatkan kemampuan berpikir kreatif dan kemampuan berpikir kritis. Salah satu masalah yang dihadapi siswa adalah materi tentang sistem organ pada manusia seperti sistem saraf karena memiliki konsep-konsep yang sulit dan tidak mudah dihafal sehingga sulit dipahami oleh siswa.

\section{METODE PENELITIAN}

Penelitian ini dilaksanakan di SMA Negeri Muara Lakitan Kabupaten Musi
Rawas Sumatera Selatan. Peneltian ini merupakan penelitian eksperimental semu. Desain penelitian yang digunakan dalam penelitian ini adalah Quasi Experimental Design dengan bentuk Nonequivalent Control Group Design kemudian diberi pretest dan postest untuk mengetahui adakah perbedaan antara kelompok eksperimen dan kelompok kontrol. Kelas eksperimen (kelas XI IPA 2) diberi perlakuan dengan Model Generative Learning, sementara kelas kontrol (XI IPA 1) diberi perlakuan pembelajaran menggunakan pembelajaran Direct Instruction.

Waktu pelaksanan ini pada Bulan April-Mei 2017. Dalam penelitian ini, teknik pengumpulan data diperoleh melalui tes dan non tes. Teknik tes menggunakan soal kemampuan analisis siswa yang diberikan sebelum dan setelah diterapkan model Generative Learning pada kelompok eksperimen dan konvensional pada kelompok kontrol.

\section{HASIL DAN PEMBAHASAN}

Hasil yang diperoleh dari penelitian ini adalah kemampuan analisis siswa setelah diterapkan model Generative Learning. Berikut disajikan hasil pretest dan posttest dari kelas eksperimen dan kontrol.

Tabel 1. Data Deskriptif Nilai Pretest pada Kelas Eksperimen dan Kelas Kontrol

\begin{tabular}{lccccc}
\hline \multirow{2}{*}{ Kelas } & \multicolumn{5}{c}{ Nilai Pretest } \\
\cline { 2 - 6 } & Sampel & Nilai KKM & Nilai Min & NilaiMax & Rata-rata \\
\hline Eksperimen & 35 & 75 & 13 & 53 & 30,51 \\
Kontrol & 34 & 75 & 20 & 73 & 42,53 \\
\hline
\end{tabular}

Berdasarkan Tabel 2 menunjukan bahwa nilai rata-rata pretest kelas eksperimen 30,51 dan nilai pretest kelas kontrol adalah 42,53. Dimana rata-rata nilai kelas eksperimen lebih rendah dari pada kelas kontrol. Perbandingan ketuntasan kemampuan analisis siswa pada pretest kelas eksperimen dan kelas kontrol dapat dilihat pada Gambar 1 berikut ini : 


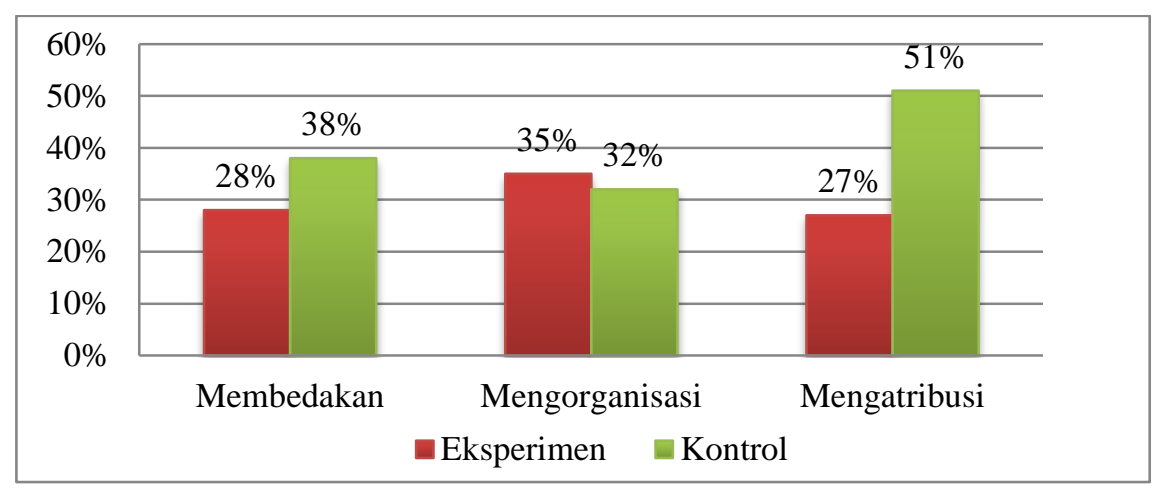

Gambar 1. Diagram Batang Persentase Ketuntasan Indikator KA Siswa pada Soal Pretest di Kelas Eksperimen dan Kontrol

Tabel 2. Data Deskriptif Nilai Postest pada Kelas Eksperimen dan Kelas Kontrol

\begin{tabular}{lccccc}
\hline \multirow{2}{*}{ Kelas } & \multicolumn{5}{c}{ Nilai Postest } \\
\cline { 2 - 6 } & Jumlah Sampel Nilai KKM & Nilai Min & Nilai Maks & Rata-rata \\
\hline Eksperimen & 35 & 75 & 40 & 93 & 67,37 \\
\hline Kontrol & 34 & 75 & 33 & 80 & 55,44 \\
\hline
\end{tabular}

Berdasarkan Tabel 2, menunjukan bahwa unggul dari pada kelas kontrol. Perbandingan nilai rata-rata postest kelas eksperimen 67,31 ketuntasan postest kemampuan analisis siswa di dan nilai postest kelas kontrol adalah 55,44. kelas eksperimen dan kontrol dapat dilihat pada Dimana rata-rata nilai kelas eksperimen lebih pada diagram batang dibawah ini :

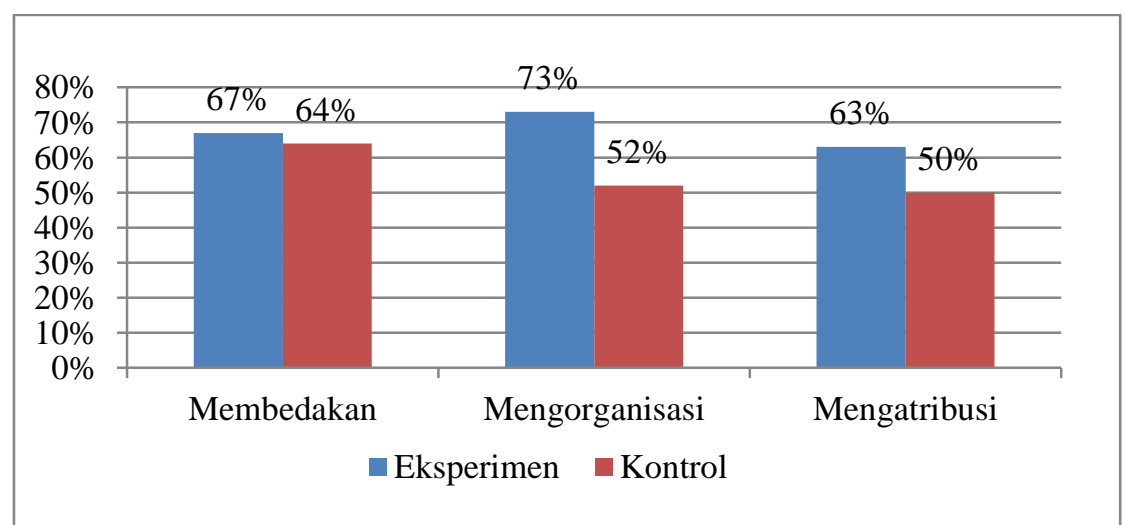

Gambar 2. Diagram Batang Persentase Ketuntasan Postest Indikator KA pada Kelas Eksperimen dan Kontrol

Selisih nilai pretest dan postest pada yang dilakukan di kedua kelas. Rata-rata nilai penelitian ini dilihat dari nilai N-Gain. Nilai N- pretest, postest, dan N-gain disajikan pada tabel gain dapat dilihat dari hasil pretest dan postest 3 berikut:

Tabel 3. Nilai N-Gain Pretest dan Postest Kelas Eksperimen dan kelas Kontrol

\begin{tabular}{lcccc}
\hline \multirow{2}{*}{ Kelas } & \multicolumn{2}{c}{ Rata-rata } & \multirow{2}{*}{ Gain } & \multirow{2}{*}{ Kategori } \\
\cline { 2 - 3 } & Pretest & Postest & & \\
\hline Kelas Eksperimen & 30,51 & 67,37 & 0,53 & Sedang \\
Kelas Kontrol & 42,53 & 55,44 & 0,19 & Rendah \\
\hline
\end{tabular}

Berdasarkan hasil penelitian, sebelum diberikan eksperimen dan kelas kontrol, terlebih dahulu perlakuan dalam pembelajaran pada kelas dilakukan pretest. Hasil rata-rata nilai pretest 
kelas eksperimen adalah 30,51 sedangkan pada kelas kelas kontrol rata-rata nilai pretest lebih tinggi yaitu 42,53. Setelah dilakuan perlakuan dalam pembelajaran, pada kelas eksperimen diberi perlakuan dengan menggunakan model Generative Learning, sedangkan pada kelas kontrol dengan menggunakan Direct Instruction. Hasil nilai postest kedua kelas masing-masing memiliki rata-rata 67,37 pada kelas eksperimen, dan 55,44 untuk kelas kontrol.

Perlakuan model pembelajaran yang berbeda pada kelas eksperimen dan kelas kontrol juga menunjukan peningkatan kemampuan analisis yang berbeda. Peningkatan tersebut dapat dilihat dari nilai $\mathrm{N}$-gain siswa yaitu selisih nilai pretest dan postest. Rata-rata nilai $\mathrm{N}$ gain pada kelas eksperimen adalah 0,53 yang termasuk dalam kategori sedang. Sedangkan rata-rata nilai $\mathrm{N}$-gain pada kelas kontrol termasuk dalam kategori rendah. Ratarata $\mathrm{N}$-gain kemampuan analisis pada materi sistem saraf untuk kelas eksperimen lebih besar dari rata-rata N-gain kelas kontrol.

Ketuntasan tiap indikator kemampuan analisis siswa juga dapat dilihat dengan cara menganalisis tiap indikator kemampuan analisis yang meliputi membedakan, mengorganisasi, dan mengatribusi dari soal pretest dan postest siswa.

Pada indikator membedakan, pada pretest di kelas eksperimen siswa yang menjawab dengan benar sebesar $28 \%$ dan saat postest meningkat menjadi $67 \%$. Sedangkan pada kelas kontrol, pada indikator membedakan saat pretest siswa yang menjawab benar sebesar $38 \%$ dan saat postest meningkat menjadi $64 \%$. Peningkatan indikator membedakan pada kelas eksperimen adalah 39\% lebih tinggi dari pada kelas kontrol yaitu 26\% dan selisih $13 \%$. Hal ini bisa dikarenakan saat proses pembelajaran siswa di fasilitasi dengan LKS yang berbasis GL dengan bentuk persoalan analisis sehingga mengajak siswa untuk lebih ikut mengidentifikasi, mengamati dan memahami suatu objek dalam materi sistem saraf manusia yang sedang dibahas sehingga ia dapat membedakan bagian yang penting dan relevan dalam materi. Hal ini sesuai dengan penelitian Sartika dan Nuroh (2016), bahwa saat seseorang mengamati suatu objek, akan tercermin untuk membedakan sesuatu yang penting dan relevan. Zahriah, Hasan \& Jalil (2016) juga menyatakan bahwa kemampuan memahami persoalan dengan baik, dapat melibatkan siswa memilah bagian yang relevan atau penting dari sebuah struktur dan menentukan informasi yang penting.

Pada indikator mengorganisasikan, pada pretest dikelas eksperimen, siswa yang menjawab dengan benar sebesar 35\% dan meningkat menjadi $73 \%$ saat postest, sedangkan pada kelas kontrol, indikator mengorganisasikan yang dijawab benar oleh siswa saat pretest sebesar $32 \%$ meningkat menjadi $52 \%$ saat menjawab soal postest. Peningkatan indikator mengorganisasikan lebih tinggi 38\% dibandingkan kelas kontrol 20\% sehingga selisih 18\%. Hal ini kemungkinan karena pada kelas eksperimen siswa tidak hanya membentuk informasi dari suatu materi pelajaran yang ia ketahui sebelumnya, tetapi juga terbiasa membangun hubungan yang sistematis antar potongan informasi dengan cara mengidentifikasi elemen yang penting dan menentukan struktur yang terbentuk saat proses pembelajaran. Sedangkan pada kelas kontrol, siswa hanya memahami informasi yang dijelaskan oleh guru. Hal ini sejalan dengan hasil penelitian Dostal (2015), menyatakan bahwa ketika siswa dapat menemukan koherensi antara apa yang diketahui dan tidak diketahui kemudian menghubungkannya sehingga pada akhirnya menemukan sudut pandang yang dapat menyelesaikan persoalan tersebut. Hasil penelitian Ratri, Suciati dan Sugiyarto. (2016) dan Agnafia (2016), juga menyatakan bahwa model GL dapat meningkatkan kemampuan kognitif 
dan kemampuan berpikir kritis siswa. Penelitian Reid and Marison (2014), juga menyimpulkan bahwa ketika model GL dilaksanakan dengan baik, menghasilkan skor atau hasil belajar yang lebih tinggi.

Pada indikator mengatribusi, pada pretest di kelas eksperimen, siswa yang dapat menjawab benar sebesar $27 \%$ dan saat postest meningkat menjadi $63 \%$, peningkatan pada kelas eksperiemen sebanyak 36\%. Sedangkan pada pretest di kelas kontrol siswa yang dapat menjawab benar sebesar $51 \%$ dan saat postest indikator mengatribusi tidak mengalami peningkatan, tetapi mengalami penurunan sebanyak $1 \%$ siswa yang menjawab benar menjadi $50 \%$ pada saat postest. Peningkatan indikator mengatribusi pada kelas eksperimen kemungkinan bisa terjadi karena siswa terbiasa melakukan komunikasi baik pada saat berdiskusi dan melakukan tanya jawab sehingga ia dapat menentukan sudut pandang, pendapat dan nilai dibalik komunikasi tersebut. Hal ini senada dengan hasil penelitian Sartika dan Nauroh (2016), saat siswa mengkomunikasi akan tercermin indikator mengatribusi dari suatu persoalan. Hasil penelitian Zahriah, Hasan \& Jalil (2016) juga menyatakan bahwa saat siswa melakukan dekontruksi untuk menetapkan tujuan yang jelas dari persoalan, itu karena siswa dapat memahami tujuan dibalik persoalan tersebut.

Peningkatan kemampuan analisis dikelas eksperimen dan kelas kontrol, indikator membedakan merupakan indikator yang mengalami peningkatan paling tinggi yaitu 39\% pada kelas eksperimen dan $26 \%$ pada kelas kontrol. Indikator yang mengalami peningkatan paling rendah pada kedua kelas adalah indikator mengatribusi dengan peningkatan $36 \%$ pada kelas eksperimen dan $1 \%$ pada kelas kontrol. Berdasarkan analisis perindikator diketahui bahwa setiap indikator kemampuan analisis dari postest mengalami peningkatan dari pretest baik di kelas eksperimen maapun dikelas kontrol. Namun peningkatan kemampuan analisis di kelas eksperimen lebih tinggi daripada kelas kontrol. Rata-rata persentase peningkatan kemampuan analisis dikelas eksperimen sebesar $37,6 \%$ sedangkan dikelas kontrol sebesar $15 \%$.

Proses pembelajaran dikelas eksperimen, yang pertama pada tahap pendahuluan, disini siswa didorong untuk mengemukakan ide atau pendapat awalnya dengan memberikan kesempatan kepada siswa untuk mengemukankan pendapatnya tentang sistem saraf manusia dan bagiannya dengan mengerjakan persoalan dasar yang diberikan pada LKS. Fase ini berfungsi mengeksplorasi pengetahuan atau konsepsi siswa terhadap materi sistem saraf manusia dari pengalaman sehari-hari atau yang diperoleh dari pembelajaran pada tingkat sebelumnya. Dari persoalan yang dibuat pada LKS siswa akan tertarik untuk mengerjakan persoalan tersebut. Menurut Nasution (2011), dengan bertanya atau memberi persoalan merupakan stimulus yang dapat mendorong siswa untuk berpikir dan belajar untuk memperoleh pengetahuannya. Pada tahap ini, kemampuan analisis yang dapat muncul pada tahap ini adalah aspek membedakan karena disini siswa akan memilah bagian yang releven dari persoalan yang diajukan sebelum mengemukakan ide dan pendapatnya mengenai sistem saraf manusia. Hal ini sejalan dengan Heong $d k k$ (2012), mengatakan bahwa membentuk ide dengan menciptakan gagasan merupakan indikasi dari proses berpikir.

Tahap model GL kedua pada kelas eksperimen adalah pemfokusan. Pada tahap ini, siswa akan belajar secara berkelompok yang terdiri 5 kelompok untuk mengerjakan LKS yang sudah disediakan, dengan cara bertukar pendapat dan berdiskusi bersama teman sekelompoknya untuk menjawab persoalan yang ada pada LKS tentang materi sistem saraf manusia yang sedang mereka pelajari. Dalam 
menjawab dan mengklarifikasi persoalan dalam LKS, siswa juga dibantu dengan buku literatur selain dari diskusi bersama temannya. Hal ini sejalan dengan pendapat Suherman (2003), dengan mengelompokkan siswa kedalam kelompok kecil memberikan peluang siswa untuk saling bertukar ide dan siswa dimungkinkan mampu menyelesaikan masalah lebih baik dibandingkan mereka bekerja sendiri.

Pada tahap pemfokusan siswa diberi kesempatan menetapkan konteks saraf pusat, gerak refleks dan saraf tepi. Siswa memahami dan mencermati hubungan antar saraf pusat, gerak refleks dan saraf tepi pada LKS yang berfungsi untuk membantu siswa mengkontruks pengetahuannya, sehingga siswa menjadi lebih familiar terhadap materi sistem saraf manusia. Sesuai dengan pendapat Pedro dkk (2002), memfokuskan melibatkan dan mengarahkan perhatian seseorang terhadap informasi yang dipilih sehingga dapat mendefinisikan dan menetapkan tujuan suatu permasalahan. Pada tahap pemfokusan, potensi kemampuan analisis yang akan muncul terutama indikator mengorganisasi dan mengatribusi karena pada tahap ini siswa mengorganisasi persoalan penting pada materi saraf pusat manusia, gerak refleks, dan saraf tepi kemudian menentukan pendapat atau sudut pandang di balik komunikasi baik saat berdiskusi dengan teman ataupun komunikasi secara tidak langsung antar guru dan siswa dari LKS yang telah diberikan.

Tahap model GL ketiga pada kelas eksperimen adalah tantangan, pada tahap ini, siswa ditantang untuk mempresentasikan dan melakukan tanya jawab dengan memberikan ide dan pendapat dari hasil diskusi pada jawaban LKS tentang sistem saraf manusia yang telah mereka kerjakan bersama-sama kelompoknya untuk dijelaskan kembali kepada kelompok lain. Pada tahap ini, siswa harus menguasai materi yang telah diperoleh, sehingga dapat menyampaikan presentasi dengan baik dan benar sesuai dengan hasil yang telah meraka buat. Senada dengan pendapat Ngalimun (2014), menyatakan bahwa siswa menjelaskan konsep hasil temuan kelompoknya dengan kata-kata mereka sendiri, menunjukkan bukti dan klarifikasi dari penjelasan mereka, serta membandingkan argumen yang mereka miliki dengan argumen dari siswa lain. Pada tahap tantangan ini, siswa memberikan pertimbangan ide dari kelompok lain dengan cara tanya jawab tentang materi sistem saraf berdasarkan hasil diskusi dari masing-masing kelompok yang telah dilakukan sebelumnya dan juga membandingkan ide kelompok dengan ide dari literatur. Potensi kemampuan analisis yang dapat muncul pada tahapan ini adalah membedakan, mengorganisasi, dan mengatribusi. Pada tahap ini, siswa memilah bagian penting dari pertanyaan kelompok lain, kemudian mengidentifikasi pertanyaan penting dari kelompok lain, kemudian menentukan tujuan dan sudut pandag dari pertanyaan tersebut. Hal ini sesuai dengan Sumantri dan Permana (2001), menyatakan bahwa penggunaan diskusi dan tanya jawab dapat mengembangkan keterampilan diri siswa seperti keterampilan berpikir, bertanya, berkomunikasi, menafsirkan dan menyimpulkan bahasan.

Tahap Model GL yang keempat adalah penerapan. Dalam tahap ini, siswa menyelesaikan permasalahan praktis yang dikemas dalam bentuk soal dengan berdasarkan kemampuan analisis yang dikerjakan secara individu yang terdapat pada LKS. Pada tahap ini, siswa menggunakan pengetahuan baru yang mereka dapat dengan menghubungakan dari pengetahuan awalnya untuk untuk lebih memunculkan kemampuan analisisnya dengan menyelesaikan persoalan materi saraf pusat manusia, gerak refleks, dan saraf tepi yang dikerjakan secara individu. Sejalan dengan pendapat Reid dan Marrison (2014), bahwa adanya permasalahan yang baru dapat diselesaikan dengan menggunakan pengetahuan 
sebelumnya sehingga menghasilkan pemikiran yang lebih dalam sehingga menghasilkan pembelajaran yang lebih bermakna. Bayer (1997) menyatakan untuk meningkatkan kemampuan siswa dengan memberikan mereka kesempatan untuk terlibat dalam jenis berpikir. Tahap ini dapat juga dijadikan sebagai evaluasi terhadap kemampuan analisis siswa terhadap materi sistem saraf manusia. Hal ini senada dengan pendapat Rustaman (2009), bahwa pertanyaan-pertanyaan yang terorganisasi dan sistematis memungkinkan siswa untuk terlibat dalam kegiatan yang membantunya untuk mendapatkan pemahaman yang mendalam.

Sintaks pembelajaran Generative Learning, memungkinkan siswa aktif memaknai apa yang sedang dipelajari, menjelaskan materi apa yang sedang dipelajari, dan menyeleksi informasi dari materi yang dipelajari berdasarkan pengalaman belajarnya, sehingga ia dapat mengingat dan mengolah informasi untuk membuat genaralisasi kemampuan analisisnya dari materi yang dipelajari. Sejalan dengan penelitian Diraksa dan Temtachatipong (2009), bahwa pembelajaran yang berupaya mengembangkan kemampuan analisisnya dan berlandaskan teori kontruktivisme akan menyebabkan siswa terpacu untuk melakukan kegiatan. Dalam model GL, guru hanya berperan membimbing dan mengarahkan siswa dengan pertanyaan-pertanyaan yang dapat menuntun siswa dalam mengkonstruksi pengetahuannya.

Hambatan yang dialami selama pelaksanaan pembelajaran, sebagian siswa bergantung dengan siswa lain saat mengerjakan LKS dan berdiskusi. Selain itu, kurang terbiasanya siswa terhadap persoalan dalam bentuk analsis. Oleh karenanya diperlukan waktu bagi siswa untuk menyesuaikan diri dengan model pembelajaran yang diterapkan. Menurut Irwandani (2015), menyatakan bahwa salah satu kekurangan pelaksanaan model pembelajaran $G L$ adalah siswa yang pasif merasa diteror untuk mengkontruksi pembelajaran selain itu memerlukan pengolahan kelas yang lebih terencana sehingga memerlukan waktu dan tenaga yang lebih banyak dalam menyusun rencana dan melaksanakan pembelajaran.

Berdasarkan uji hipotesis menggunakan uji t kelas eksperimen dan kelas kontrol yang didapat adalah $\mathrm{t}_{\text {hitung }}=3,969>\mathrm{t}_{\text {tabel }}=1,670$ dengan signifikasi $0,000<0,05$, maka diambil keputusan bahwa $\mathrm{H}_{0}$ ditolak dan $\mathrm{H}_{\mathrm{a}}$ diterima. Artinya terdapat perbedaan kemampuan analisis siswa pada materi sistem saraf manusia di kelas eksperimen dan kelas kontrol. Perbedaan kemampuan analisis siswa bisa terjadi karena penerapan model pembelajaran yang berbeda pada kelas eksperimen dan kelas kontrol. Hal ini sesuai dengan pendapat Arends (2008), yang menyatakan bahwa model pembelajaran dapat membantu siswa mendapatkan informasi baru, membelajari berbahai keterampilan penting dan memproses informasi yang sudah diperoleh.

\section{SIMPULAN DAN SARAN}

Berdasarkan hasil penelitian dapat disimpulkan bahwa penerapan model Generative Learning memberikan pengaruh terhadap kemampuan analisis siswa pada materi sistem saraf manusia. Ketuntasan indikator kemampuan analisis pada kelas eksperimen $67,7 \%$ lebih tinggi dari pada kelas kontrol yaitu $55,3 \%$. Peningkatan kemampuan analisis dari nilai pretest dan postest dapat dilihat dari nilai $\mathrm{N}$-gain dimana kelas eksperimen memiliki nilai $\mathrm{N}$-gain 0,53 lebih tinggi dari pada kelas kontrol yaitu 0,19. Nilai $\mathrm{N}$-gain kemampuan analisis kategori rendah pada kelas eksperimen lebih sedikit dibandingkan kelas kontrol. Kemampuan analisis paling tinggi terlihat pada indikator mengorganisasi.

Saran untuk penerapan model pembelajaran Generative Learning agar lebih efektif proses pembelajaran di kelas, guru harus 
mampu mengawasi kegiatan pembelajaran dan memberikan pengarahan serta bimbingan.

\section{RUJUKAN}

Agnafia, D.N. (2016). Pengembangan Modul Berbasis Generative Learning Materi Keanekaragaman hayati untuk Meningkatkan Kemampuan Berpikir Kritis Siswa SMAN 1 Kedunggalar Ngawi. Tesis Universitas Sebelas Maret.

Anderson, L.W dan David, R.K. (2015). Kerangka Landasan untuk Pembelajaran, Pengajaran dan Asesmen. Terjemahan :Prihantoro. Yogyakarta :Pustaka Pelajar.

Arends, R. I, (2008). Belajar untuk Mengajar Buku satu dan dua, Cet. Ketujuh. Yogyakarta :Pustaka Pelajar.

Atika, S, Isnaini, W, dan Prasetyo, A.P.B. (2012) Pengaruh Pendekatan Problem Based Learning dalam Materi Pencemaran Lingkungan terhadap Kemampuan Analisis. Jurnal Of Biology Education Vol.1 No. 3: 219-227.

Bayer, B.K. (1997). Improving Student Thinking a comprehensive approach. MA : Allyn \& Bacon.

Diraksa, T. dan P. Termtachatipong. (2009). The Development of Grade 10 Students Analytical Thinking Ability and Learning Achievement About Heredity by Using Conastuctivist Theory Teaching Strategies Based on Underhill Approach. Penang. Third International Conference on Science and Mathematics Education (CoSMEd).

Dostal, J. 2015. Theory of Problem Solving. Procedia Social and Behavioral Science 174:2798-2805.

Hasbullah.2012.Dasar-Dasar Ilmu Pendidikan (Umum dan Agama Islam). Jakarta: Rajawali Pers.

Heong, Y.M., Othman, W., Yunos, J., Jiong, T., Razali.,dan Mohamad M. (2012). The Need Analysis of Learning Higher
Thinking Skills for Generating Ideas. Journal Social and Vehavioral Science 59-197-203.

Heong Y.M., Othman W.D.,, Yunos J,B., Kiong T.T., Hassan R.B., Mohamad M.M.B. (2011). The Level of Marzano Higher Order Thinking Skills Among Technical Education Students. International Journal of Social Science and Humanity, Vol. 1, No. 2:121-125.

Irwandani. (2015). Pengaruh Model

Pembelajaran Generatif Terhadap

Pemahaman Konsep Fisika Pokok

Bahasan Bunyi Peserta Didik MTS AlHikmah Bandar Lampung. Jurnal Ilmiah Pendidikan Fisika Al Biruni. Vol.04 No.2: 165-177.

Kemendikbud, (2015). PISA (Programme For Internasional Students Asessment) (Online) tersedia : http://litbang. kemdendikbud.go.id/index.php/surveiinternasional-pisa.

Nasution. S, (2011). Berbagai Pendekatan Dalam Proses Belajar Mengajar. Jakarta : PT BumiAksara.

Ngalimun. (2014). Strategi dan Model Pembelajaran. Yogyakarta: Aswaja Presindo.

Nurmalasari, I. (2016). Pengaruh Model Project Based Learning terhadap Kemampuan Analisis pada Konsep Protista. Online. Repository.uinjkt.ac.id/dspace/bitstream/.. ./3/IRMA\%20NURMALASARI-

FITK.pdf.3 November 2016.

Pedro, L.A., Navales, M.A., Josue. F.T. (2002). Improving Analizing Skills of Primary Student Using A Problem Sloving Strategy. Journal of Science and Mathematics Education Asia. Vol. 27, No 1: 33-53

Ratri, E.F.,SuciatidanSugiyarto. (2016). Keefektifan Model Probem Based Learning, Model Generative Learning dan 
Integrasinya terhadap Hasil Belajar ditinjau dari Kemampuan Menganalisis dan Kreativitas Siswa. Jurnal Inkuiri. Vol 5, No. 1: 95-104.

Ratumanan, (2015). Inovasi Pembelajaran. Yogyakarta : Ombak

Reid, A.J dan Marrison G.R. (2014). Generative Learning Strategy used and SelRegulatory Prompting in Digital Text. Journal of Information Technology Education 13: 50-72.

Rustaman

StrategiBelajarMengajarBiologi. Malang. UM Press.

Sartika, S.B dan Nuroh, E.Z. (2016). Implementasi Pembelajaran IPA Berbasis Pendekatan Ketarampilan Proses Sains untuk Melatih Keterampilan Berpikir Analisis Siswa SMP. Pros. Semnas Pend. IPA Pascasarjana UM. Vol 1: 1071-1080.

Sugilar, H. (2013). Meningkatkan Kemampuan Berpikir Kreatif dan Diposisi Matematik Siswa MTs Melalui Pembelajaran Generatif. Infinity Journal. Vol 2. No.2 : 156-168.
Suherman, E. (2003). Evaluasi Pembelajaran Matematika. Bandung : JICA UPI.

Sumantri, M., dan Permana, J. (2001). Strategi Belajar Mengajar. Bandung L Bumi Aksara.

Syah, M. (2010). Psikologi Pendidikan : dengan Pendekatan Baru. Bandung: Remaja Rosdakarya.

Wena, M. (2014). Strategi Pembelajaran Inovatif Kontemporer suatu Tinjauan Konseptual Operasional. Jakarta : Bumi Aksara.

Wijaya, I.K.W.B., Suastra I.W dan Muderwan, I.W. (2014). Pengaruh Model Pembelajaran Generatif terhadap Keterampilan Berpikir Kreatif dan Keterampilan Proses Sains .E-Journal Program Pascasarjana Universitas Pendidikan Ganesha. Vol 4. No.1: 1-11.

Zahriah.,Hasan, M., dan Jalil, Z. (2016). Penerapan Pemeacah Masalah Model Polya untuk Meningkatan Kemampuan Analisis dan Hasil Belajar pada Materi Vektor di SMAN 1 Darul Imarah. Jurnal Pendidikan Sains Indonesia. Vol 04, No. 02: 151-161. 